\title{
Social Science Research in The University: An Examination of the Views of Harry Cassidy and Harold Innis
}

\author{
ALLAN IRVING*
}

\begin{abstract}
Harry Cassidy and Harold Innis, both of the University of Toronto, and both notable Canadian academics, became well known in their respective fields: Cassidy in social welfare and Innis in economic history. This article examines their quite individual approaches to university social science research during the 1940 's. Cassidy's orientation was pragmatic and motivated by a Fabian outlook that a carefully-laid foundation of facts was necessary in the process of social reform and for the development of progressive social welfare policies. Innis's approach to social science research was much more speculative and historical. It was his contention that long-range social science research carried out by universities could contribute to the restoration of a declining Western civilization. Since he never fully developed his position on research, this account is a synthesis based on his essays. This article, based on material in the University of Toronto Archives, reviews Cassidy's attempts during the forties to have an Institute for Research established at the University of Toronto, which would conduct research into problems of social security in Canada. Some current concerns regarding social science research in the university are discussed in the conclusion.
\end{abstract}

\section{RÉSUMÉ}

Harry Cassidy et Harold Innis devinrent tous deux célèbres dans leur domaine: Cassidy en bien-être social et Innis en histoire économique. Cet article examinera en quoi leurs recherches sur les sciences sociales universitaires dans les années 40 diffèrent.

$L$ 'orientation de Cassidy était pragmatique et motivée par le point de vue de Fabian qui pensait qu'une bonne organisation de base était nécessaire au processus de réforme sociale et au développement de la politique progressive du bien-être social. Nous montre- 
rons comment, à cette époque, Cassidy a essayé de créer un Institut de Recherche à l'Université de Toronto. Il espérait, grâce à cet Institut, commencer des recherches sur les questions de sécurité sociale au Canada. Ces informations viennent des archives de l'Université de Toronto.

L'approche d'Innis était plus spéculative et historique. Il soutenait que la recherche des sciences sociales à longue portée, faites par les Universités, pouvait contribuer à la restauration d'une civilisation occidentale en déclin. Innis n'a jamais pleinement exposé sa position quant à la recherche et nous essaierons de faire une synthèse de ses travaux.

A la fin de ce travail, nous montrerons un tant soit peu quel est l'intérêt actuel envers l'étude des sciences sociales dans les Universités.

The problem of the social scientist is the problem of the university.

- Harold Innis (1935)

When Harry Cassidy left his position as an Assistant Professor of Social Science at the University of Toronto in 1934 to become the Director of Social Welfare for British Columbia, he wrote to the University's President, H.J. Cody: "I can assure you that I appreciate very much your tolerance of faculty members such as myself expressing unorthodox ideas and of our being given genuine freedom in the University of Toronto to discover and express the truth as we see it - even if we may be wrong." 1 Cassidy was referring to his involvement with the League for Social Reconstruction and to his Cooperative Commonwealth Federation (CCF) activities. In the early 1930's, Cassidy had helped to establish the League, which was the Canadian counterpart of the British Fabian Society, and which had quickly become known as the CCF 'brains trust'. Members of the League, including Cassidy, had helped Frank Underhill write the original drafts of the Regina Manifesto of $1933 .^{2}$ Later in the decade, while he was a civil servant in British Columbia, Cassidy campaigned actively for the CCF.

In January of 1945, Cassidy returned to the University of Toronto as Director of the School of Social Work. In June of 1944, when the appointment was being negotiated, Harold Innis, then Chairman of the Department of Political Economy and of the Council of the School of Social Work, wrote to President Cody to protest the appointment. Innis strenuously objected to university teachers engaging in partisan political activities on the grounds that such activities compromised their ability to conduct independent research. "The CCF to my mind and as far as research in a university is concerned," he wrote, "sins against the light." Innis added that his resignation as Chairman of the School of Social Work Council would "avoid embarrassment to you and me in case the plans with regard to Dr. Cassidy are carried through." 4

This article examines the different approaches of Cassidy and Innis to university social science research, and looks at Cassidy's attempts to have his plans for research implemented within the University. Cassidy's orientation to social science research was essentially pragmatic. Behind it was the Fabian view that a carefully-laid foundation of facts was essential if governments were to be persuaded, by rational argument, of the need for social reform, and particularly of the need for progressive social welfare policies. Innis' approach was much more historical and philosophical: long-range social science research could contribute 
significantly to the restoration of a declining Western civilization. Undoubtedly Cassidy's practical approach was related to his spending almost all of his academic career in a professional department; Innis's more speculative outlook certainly was influenced largely by the more theoretical traditions of political economy. A description of the careers of Cassidy and Innis precedes the detailed discussion of their perspectives on research. In the conclusion some current concerns regarding social science research in the university are discussed.

Harold Innis (1894-1952) was born on a farm near the village of Otterville, Ontario, and he attended public and high schools in the area. He received his B.A. and M.A. from McMaster University, and, in 1920, his Ph.D. in Economics from the University of Chicago. During his studies at Chicago, Innis was influenced significantly by the thought of Thorstein Veblen, and something of Veblen's scepticism always remained with him. ${ }^{5}$

In 1920, Innis was appointed as a lecturer in the Department of Political Economy at the University of Toronto, where he remained for the rest of his life. In 1937, be became Chairman of the Department of Political Economy, and, in 1947, Dean of the Graduate School. In 1946, Innis was elected President of the Royal Society of Canada, and, at the end of his life, he was elected President of the American Economics Association. He also served on three Royal Commissions.

Innis wrote and published continuously; a recent bibliography of his writings is twentyfive pages long. His first book, published in 1923, A History of the Canadian Pacific Railway, was based on his thesis. In 1930, his reputation as an economic historian of the first rank was assured with the publication of The Fur Trade in Canada: An Introduction to Canadian Economic History: "It is doubtful that any other Canadian monograph. . . has had an equal impact on Canadian intellectual life." 6 The book was a reinterpretation of Canadian economic and historical development, and its unorthodox conclusion was that "the present Dominion emerged not in spite of geography but because of it." 7 With this book, Innis emerged as the foremost interpreter of the staple theory of development: "the idea that the exploitation of a succession of staple commodities explained the nature of Canadian development and the singular patterns of its institutions and culture." 8 In 1940, he published another monumental study, The Cod Fisheries: The History of an International Economy, which enhanced his international reputation as an economic historian. After 1940, he became increasingly interested in the interrelationships of technology, the media of communication, and world cultures. His inquiries focused on the historical development of the media of communication and their significant influence on the rise and fall of civilizations. During the 1940's Innis became dismayed by the modern media of communication, such as radio, that played "on the surfaces of minds that had been adroitly robbed of all their roots in time." 9

It was Innis's view that modern civilization was in a perilous state of decline; this outlook ultimately determined his perspective on university research. His last four books, Political Economy in the Modern State (1946), Empire and Communications (1950), The Bias of Communication (1951), and Changing Concepts of Time (1952), were devoted largely to an exploration of the themes of communications, long-range research, the role of the university and its scholars, and the decline of Western civilization. In reaching his original conclusions, Innis successfully combined painstaking research and bold speculation: "He possessed in an unusual degree that rarest of academic gifts, the scholarly imagination." 10 
Harry Cassidy (1900-1951) was born on a farm near the village of Murrayville, British Columbia. He completed his undegraduate education at the University of British Columbia and received his Ph.D. in Economics from the Robert Brookings Graduate School of Economics and Government, Washington, D.C., in 1926. In 1929, after three years as an Assistant Professor of Economics at the University of North Carolina and Rutgers University, he joined the Department of Social Science (which, in 1941, became the School of Social Work) at the University of Toronto, where his creative work in the social welfare field began. He remained there as an Assistant Professor until 1934, when he was asked to become Director of Social Welfare for the Province of British Columbia by the reformoriented Liberal government of T. Dufferin Pattullo that had been elected the previous year. ${ }^{11}$ From 1939 to 1944 , he was a Professor and then Dean of the School of Social Welfare at the University of California. From 1945 until his death in 1951, he was the Director of the School of Social Work at the University of Toronto which, under his leadership, became Canada's most prominent institution for social work education. Cassidy was involved in a great many other activities during his career: he served as Director of Training for the United Nations Relief and Rehabilitation Administration (UNRRA), in 1944.45, and as Technical Adviser on Social Security to the Canadian Department of National Health and Welfare in 1947.

In 1931, Cassidy became involved with the Unemployment Research Committee of Ontario, a group of citizens who had become convinced of the need for investigating and collecting data on unemployment. The next year, he published Unemployment and Relief in Ontario 1929-1932: A Survey and Report, based on a study that he had conducted for the Committee. It was the first book on unemployment relief in Canada. When the League for Social Reconstruction was established in 1932, Cassidy became the Director of its Research Committee; he wrote two chapters for the League's book, Social Planning for Canada (1935). In 1935, Cassidy, in conjunction with F.R. Scott, published Labour Conditions in the Men's Clothing Industry, a report that had been commissioned by the Amalgamated Clothing Workers of America, a trade union and by the Canadian Association of Garment Manufacturers, an employers' association. In the 1940's, he published Social Security and Reconstruction in Canada (1943), which outlined his proposals for a comprehensive system of social security, and Public Health and Welfare Reorganization (1945), which provided more detail on the same basic subject.

Behind Cassidy's approach to the resolution of social problems there was an insistent, driving energy and a sense of urgency. Shortly after his death, a close friend commented that "Harry was never a consolidator - he was a creator, a builder. An inner compulsion drove him on and on." 12

Unlike Cassidy, Harold Innis never fully developed his position on research, and the following account is a synthesis based on a number of Innis's essays. ${ }^{13}$ In 1953, Marshall McLuhan commented that "many readers of the last. . volumes of Innis express their inability to find what he was driving at. They can't formulate his position. This is no accident. The later Innis had no position." 14 While Innis's position cannot be formulated precisely, its broad outlines can be discerned: Western culture could be saved from extinction only if the university and its scholars would focus on the long-range problems plaguing civilization. Social science research in the university had a meaning and purpose for Innis that were inextricably bound up with his criticisms of Western civilization and of the contemporary practices of universities. 
From about 1940 on, Innis became increasingly convinced that technology, particularly the technology of communication, was the primary factor that determined the shape of society and, ultimately, the rise and fall of civilizations: "Once Innis had ascertained the dominant technology of a culture he could be sure that this was the cause and shaping force of the entire structure." ${ }^{15}$ Central to Innis's argument was his observation that all communications media were biased either in the direction of space or in the direction of time. Communications media such as stone or clay tablets - the media of earlier cultures - which were heavy and durable, stressed the dimension of time. Media such as papyrus or paper that were light and that could be transported quickly and easily from one place to another focused on the space dimension. "Time-biased media favoured institutional decentralization and the sacred, religious, and historical. Space-biased media were associated with secularism, centralization, bureaucracy, state authority, territorial expansion, and technical administration." 16 A civilization could be healthy and stable only if the media of communication resulted in a balance between the space and time dimensions: "In Western civilization a stable society is dependent on an appreciation of a proper balance between the concepts of space and time." ${ }^{17}$ Innis identified two civilizations that had achieved the desired balance: the Greek and the Byzantine.

It was Innis's contention that twentieth-century Western society was in an advanced state of disintegration, which was reflected in the fact that the "stability which [had] characterized certain periods in earlier civilizations [was] not the obvious objective of this civilization." 18 What lay behind the decline of Western civilization were the modern media of communication, such as newspapers and radio, which had created instability by emphasizing the dimension of space over the dimension of time. Furthermore, "mechanized communication divided reason and emotion and emphasized the latter." 19

Innis also observed that "states are destroyed by ignorance of the most important things in human life, by a profound lack of culture - which, following Plato, is the inability to secure a proper agreement between desire and intellect." ${ }^{20}$ The university, as the "institution which has played the leading role in the flowering of Western culture," had a central place in Western civilization. ${ }^{21}$. The health of the one depended on the health of the other; the liberal university tradition had to be maintained or Western culture would disappear. The only possible remedy for the mounting chaos of contemporary society was to emphasize the role of reason in society and to focus on an analysis of the long-term factors in a culture's development. As an institution that traditionally had stressed the primacy of reason, the university would have to play a major part in the re-ordering of Western society. ${ }^{22}$

However, for Innis, the universities and Western civilization had declined pari passu during the twentieth century. Both had lost balance and perspective. "The University," he wrote, has "lent her ear to those who on all sides told her they had discovered truth," and has forgotten "that her existence depend[s] on the search for truth and not on truth." 23 Universities, he suggested, had tended to become "congeries of hardened avid departments obsessed with an interest in funds in which the department which can best prove its superficiality or its usefulness is most successful. Governments have been insensitive to the crucial significance of a balanced unity in universities and have responded to the pleas of specific subjects with the result that an interest in unity has been distorted to give that strange inartistic agglomeration of struggling departments called the modern university." ${ }^{24}$ Innis concluded: "The impression that universities can be bought and sold, held 
by businessmen and fostered by university administrators trained in playing for the highest bid, is a reflection of the deterioration of western civilization. To buy universities is to destroy them and with them the civilization for which they stand.... The descent of the university into the market place reflects the lie in the soul of modern society." ${ }^{25}$ It was Innis's contention that nothing was more indicative of the decline of Canadian cultural life after World War I than the infiltration of politics into the universities. ${ }^{26}$ In 1936, in a thinly veiled reference to Cassidy and other academics who were members of the League for Social Reconstruction and of the CCF, Innis observed that "foot-loose adventurers in universities turn in some cases to business and its profits during booms, and in others to political activity and popular acclaim during depressions." 27

There are several related concepts that need to be examined for a complete understanding of Innis's interpretation of the condition of the university and the social sciences, and of the place of research: specialization, bias, and the cult of "present-mindedness" with its emphasis on short-range research. Specialization resulted in the social sciences becoming, much to Innis's dismay, more and more oriented towards the quantitative and generally concerned only with the immediate. Specialization ultimatley resulted in a loss of perspective and in a decline of both universities and Western society. He caustically remarked that "work in the social sciences has become increasingly concerned with topical problems and social science departments become schools of journalism." ${ }^{28}$ In order to escape the emphasis on the immediate, Innis believed that it was necessary to develop a comprehensive philosophy of the social sciences which would stress, above all else, their limitations; it was his view that his own field of economic history could assist substantially in determining the boundaries of the social sciences.

The ultimate concern of the social scientist should be to recognize not only his own personal bias, but also the biases of particular historical periods: "The habits or biases of individuals which permit prediction are reinforced in the cumulative bias of institutions and constitute the chief interest of the social scientist." ${ }^{29}$ Innis wrote - and this is one of the keys to an understanding of his total outlook - that "my bias is with the oral tradition, particularly as reflected in Greek civilization, and with the necessity of recapturing something of its spirit." 30 This spirit could never be recaptured if the bias of universities in general and of social science research in particular continued to focus on "present-mindedness," a cult of the present.

Innis lamented that "present-mindedness. . has dominated research in the social sciences in the period between the two wars." 31 The increasing attraction of shortterm government research contracts, which usually focused on some current problem of public policy, would draw social scientists more and more away from fundamental and independent research. The inherent danger, Innis recognized, was that the academic profession could very easily become "a standing surplus labour pool to meet the varying demands of governments." 32 Ultimately social scientists would be so enmeshed in government work that they would lose the ability to carry out research that had the free pursuit of truth as its main motivation.

The restoration of the universities to a more traditional role in society and, ultimately, the regeneration of society itself, depended on the approach to research adopted by the universities: research should be long-range, concerned with historical trends, and should emphasize a search for patterns of development. Innis believed that research of this nature 
could "break the strong hold of the present on the mind." ${ }^{33}$ It could best be carried out in the social sciences, in particular in economic history which, of all the social sciences, most emphasized an historical perspective. Once a long-range approach to research was adopted, the biases and loss of perspective that characterized contemporary society would begin to be revealed. The cult of the present with its "time-denying mind" could be replaced by something of the spirit of Greek civilization, with its oral tradition. That tradition "inherently involves personal contact and a consideration for the feelings of others, and it is in sharp contrast with the cruelty of mechanized communication and the tendencies which we have come to note in the modern world." 34

Ultimately, what Innis desired was a stable society, perhaps even permanence beyond change; he regretted that "the form of mind from Plato to Kant which hallowed existence beyond change is proclaimed decadent." ${ }^{35}$ Innis was undoubtedly drawn to the Platonic conception of a changeless world of ideal forms that lie behind the ever-changing world of becoming and the transitory nature of daily life.

The arguments advanced by Innis to demonstrate the need for long-range research are constantly in danger of slipping into circularity. On the one hand, long-range research is necessary to reveal the nature of the imbalances in society and the desirability of returning to something of the spirit of the Greek tradition; on the other hand, the lack of balance and perspective, and the inherent desirability of the oral tradition, show the need for long-range research into the current, disintegrating state of affairs. Despite the apparent contradiction, it was Innis, as McLuhan has remarked, who "taught us how to use the bias of culture and communication as an instrument of research." ${ }^{36}$

In the summer of 1939 , A.E. Grauer, who had been the head of the Department of Social Science at the University of Toronto since 1937, suddenly resigned. President Cody wrote to Harry Cassidy to inquire whether he might be available to direct the Department. At that time, Cassidy was unable to consider returning to Toronto, since he had just accepted a position as Director of the Department of Social Welfare at the University of California. Cassidy did tell Cody, however, that if he were to come to Toronto at some future time, it would be with the intention of developing a school of social work that would be the leader in Canada. Essential to this development would be a program of social research: "Faculty members should be equipped to serve governments through making surveys, serving as advisors, and undertaking research projects." 37

Despite one other attempt by Cody later in 1939 to persuade him to return, Cassidy remained in California until 1945. However, he did not forget Toronto: in the spring of 1943, he sent to Cody a thirty-two page document entitled "Research in Social Security - A Plan for an Institute at the University of Toronto," in which he proposed that a research institute be established in the University. He cautioned, however, that it might be best not to link his name or personal interest with the overall plan because some of his former academic associates at Toronto might still feel that his "interests in current social problems and in administration reflected a lack of academic solidity." 38

In Cassidy's view, there was an urgent need for research into problems of social security in Canada. He pointed out that, while the Institute for Research "would be concerned with fundamental questions of social science, it would not be narrowly academic, but would endeavor to provide a research and planning service of practical value to assist in [the] solution of the great problems of post-war planning." 39 It would, therefore, 
"represent as practical a contribution by the university towards the solution of current problems as that of the Connaught Laboratories in the field of medicine, that of the Ontario Research Foundation in the field of industrial development, or that of the Dominion experimental farm in the field of agriculture." 40 Canada was much less prepared than the United States or Britain to solve "the major technical problems of a total national system of social security." For one thing, Canada did not have the "significant backlog of ideas" that social security planners in Britain and the United States could draw on. ${ }^{41}$

Despite his positive attitude towards professors serving government research interests, Cassidy thought that, by itself, government research into problems of social security would not be sufficient, since "there are many analytical and interpretive studies which ought to be undertaken by research workers who are completely free of government." ${ }^{42}$ Here his arguments paralleled those of Innis: people engaged in research independent of government control would be much more free "to 'follow the evidence wherever it leads' and to reach conclusions without reference to political considerations." 43 The universities were, Cassidy declared, "the institutions par excellence to sponsor this non-governmental research."44

As Cassidy envisaged it, the proposed research institute would have five functions:
(a) To make basic studies in social security. This would include social insurance, all forms of relief and pensions, as well as related services such as employment offices, public health and medical care, child welfare, mental hy giene, vocational rehabilitation, and control of delinquency. Fundamental studies on the statistics of the social services, on their historical background, on their organization and administration, on their finances, and on their standards of operation would be undertaken by the Institute, as well as on basic social problems such as unemployment, old age insecurity, rural poverty, sickness and disability and particularly on intergovernmental relations in the social security field.

(b) To provide a public service of research, advice and planning. This would be available, at a fee, for governmental agencies or private organizations desiring social surveys or other assistance involving skilled research service.

(c) To publicize the results of research. This might be done, not only through technical books and reports, but also through popular articles, press releases, and radio broadcasts, in order to further public understanding of social security problems.

(d) To build up, in cooperation with existing university libraries, a specialized collection of materials on social security. With the materials already on hand at the University of Toronto, some intensive work should make it possible to develop at Toronto much the best collection of social security books and documents in Canada within two or three years.

(e) To contribute to the training of students. Members of the research staff might do a limited amount of teaching. In addition, the Institute would provide a training ground in research for advanced students. ${ }^{45}$

Although the thrust of Cassidy's proposals tended to be 'present-oriented', historical considerations were not to be overlooked. "Much needs to be done," he wrote, "province by province and service by service, to explore the background of the Canadian social 
services, so as to discover more clearly trends and problems that will aid in the understanding of current issues. Historical studies would provide most valuable literature for the training of students and the education of the general public." 46

The Institute for Research would be organized as a separate unit within the University, with its own staff and budget. Its director would report directly to the President. An advisory committee would be established and would include, among others, the heads of the Department of Political Economy, the School of Social Work, the Department of Psychology, and the University of Toronto Press. Initially, the staff of the Institute would consist of the director and two research assistants. Cassidy suggested that a budget of $\$ 20-25,000$ a year for at least five years would be necessary to get the program well under way. Funds would be sought from a number of sources, including the University, the Ontario Research Foundation, the Canadian Manufacturers' Association, the Canadian Congress of Labour, the Canadian Bankers' Association, and governments at all three levels, as well as from public service organizations such as the Canadian Welfare Council.

In making the case for a separate institute for research, Cassidy noted that the faculty members who were most likely to be interested in social security research - those in schools of social work across Canada - were few in number and had heavy teaching responsibilities: "They are heavily burdened by teaching and community obligations, and they have but little time or energy for serious investigation." 47 The Institute would, however, provide opportunities for members of the School of Social Work to conduct social service research. It would also provide such opportunities for members of the Department of Political Economy and other related branches of the University. At the conclusion of his proposal, Cassidy wrote that a research institute "may well bring international prestige to the University, for research in social security is a comparatively undeveloped field throughout the world."48

President Cody did not reply to Cassidy regarding the proposal, but he told Agnes McGregor, the Associate Director of the School, that Cassidy's ideas were of considerable interest. Finally, in May of 1944, President Cody did write to Cassidy, to offer him the directorship of the School of Social Work. In his letter, Cody remarked that the Provincial Government wanted the University to undertake more research work in the social sciences and that he wanted Cassidy to devote himself to directing a substantial amount of that research. However, Cody had one reservation: he was worried about Cassidy's previous political affiliations. Accordingly, he sought assurance that Cassidy would not take any part in party politics but would devote himself exclusively "to finding the facts, interpreting them, and applying this knowledge to the solution of practical problems." 49

During the negotiations that took place over the next two months, Cassidy in turn sought assurance from President Cody that funds would be made available for a research program within the School of Social Work which would work closely with the Ontario Department of Public Welfare. Cassidy informed Cody that the "provision for research means a great deal to me. . . It means the tools of my trade, without which my personal efficiency and usefulness is gravely handicapped." 50 In July 1944, Cassidy agreed to return to the University of Toronto as the Director of the School of Social Work; although he was on the staff as of July 1, 1944, he did not take up his duties until January 1, 1945, after he had completed a six-month contract with UNRRA. 
In the spring of 1945 , Cassidy outlined his plans for the development of the School during the next few years in a memorandum entitled "A Programme for the School of Social Work." As always, social research was uppermost in his mind: "The need for research in the field of the social services is outstanding," he wrote, and "a special research programme should be initiated as soon as possible." 51 He again argued for the establishment of a research institute, which would, among other things, "help regular staff members ... in carrying on their own research" and which "would assume major responsibility for the collection of significant Canadian documents." 52 Cassidy stressed the need, not only for a greater quantity of research, but also for vast improvements in the quality of the research carried out by faculty members.

Cassidy was unrelenting in his attempts to have social research programs organized. In March of 1946, he sent a memorandum, "Research in the School of Social Work," to the new President, Sidney Smith. He explained that several memoranda on social research had already been submitted to the former President and that, while certain limited developments had taken place, an institute for research had not yet been established. It was Cassidy's opinion that the proposed institute would give the School of Social Work "the resources for developing experts in certain fields such as are not now available in Canada"; fields such as delinquency control, social insurance, public medical care, and public assistance. ${ }^{53}$ Later that same year, Cassidy wrote to Smith again; this time, he enclosed the full memorandum on social security research that he had sent to President Cody in 1943, and he expressed the desire to meet with President Smith to discuss research policy.

In the fall of 1949 , Cassidy prepared yet another lengthy memorandum, entitled "Some Principles of School Policy," which, like the 1945 memorandum, outlined his plans for the development of the School. The memorandum stated that the School of Social Work's "first function is the organized study of a field entitled 'social work' and the enlargement of this field of knowledge by research." 54 Cassidy argued that research should be placed ahead of teaching in importance, since there could be no effective teaching without a body of knowledge to be taught. He was convinced that research was "the very essence of the work of the university." 55 The term 'research' was intended, Cassidy noted, "to cover more than the 'original research' of the traditional graduate thesis. In the broad it is meant to include the full process of study, observation, discussion, and contemplation which is involved in the constant cultivation of a body of knowledge by such professional students of the subject as a faculty group. The work of the professor in his study, as he reads his professional literature and prepares for his teaching, falls in this category as well as his efforts of original investigation." 56

In August of 1950, Cassidy sought permission from President Smith to approach certain private funding organizations, such as the Atkinson Foundation, for support for various research projects at the School of Social Work. Cassidy believed that the Atkinson Foundation might support social science research, and he was prepared to ask for $\$ 25,000$ a year for the next five years. By this time, Cassidy had abandoned the idea of a separate research institute, and he now suggested that a research division be established within the School. This division would be set up in such a way that, every four years, each faculty member would have a year completely free for research.

In April 1951, seven months before he died, Cassidy prepared the final draft of what was to be his last memorandum on research. The sixty-five page document, entitled 
"Research in Social Welfare," analyzed the factors which had impeded progress in research at the School, and called for the establishment of a research division within the School. The new division would have its own budget, to be supported through special donations by foundations, and would require the appointment of additional faculty members.

While Cassidy had abandoned his plan for a separate research institute by this time, he had not altered his views on social research as it related to the field of social work; in his final memorandum, he restated many of the points he had made in 1943. He again stressed that there were limits to the nature and effectiveness of governmental research in the social welfare field which related to problems of confidentiality, of departmental jurisdiction, and of concentration on the here and now. In recognizing the limits to research which focused on the here and now, Cassidy was verging towards the position adopted by Innis: "The more fundamental research questions, those of theoretical interest and of great longterm importance, are likely to be sacrificed to those of immediate concern." 57 There were limits, also, to the effectiveness of research sponsored by business and labour organizations which left "the universities as the most appropriate agencies to undertake the greater part ...of the more fundamental, critical, and impartial research which is required in the social field." ${ }^{58}$ Cassidy also stressed again the need for historical studies: "Much should be done, province by province and service by service to explore the historical background of the social services so as to discover more clearly issues and trends which throw light upon current problems and questions of policy. Historical studies will be invaluable for the training of students and the education of the general public." 59

Cassidy outlined a number of principles that should govern research policy at the School of Social Work: every faculty member should be given a substantial amount of time for research; research and teaching should be complementary; staff and student research should be closely related; the faculty research program should represent a cooperative effort; the program should reflect the current interests and problems in the field of Canadian social welfare; and there should be provision for the publication of research findings. In concluding his report, Cassidy noted that experience at the Toronto School of Social Work and elsewhere clearly had demonstrated the need to make special provision for research if constructive and creative work was to be carried out. The organizational problem could be resolved very easily, Cassidy felt, by the establishment of an administrative unit, the proposed research division within the School. "The plan," Cassidy wrote, "grows out of an enthusiastic desire of the faculty to move forward vigorously in a cooperative research enterprise and to make a distinctive contribution to scientific knowledge and to the cause of social welfare"; to support the research plan was to invest "in the cause of social enlightenment." 60

In his 1951 memorandum, Cassidy pointed out that the field of social welfare represented a new branch of social science which was still in the process of emancipating itself from the older disciplines: "It is peculiar in that it stems not from any one branch of social science but from several - notably economics, politics, sociology, psychology." 61 It was its interdisciplinary nature, Cassidy suggested, that created the need to pay special attention to the field of social welfare research.

Cassidy's research memorandum was discussed at a meeting of the Council of the School of Social Work (the governing body of the School) on February 22, $1951 .^{62}$ Among the members of the Council present at that meeting were K.S. Bernhardt, a member 
of the Department of Psychology and Assistant Director of the Institute of Child Study; George Tatham of the Department of Geography; J.A. MacFarlane, Dean of the Faculty of Medicine; and S.D. Clark of the Department of Political Economy, whose historical approach to sociology has been described as "a logical extension of Innisian social science." 63

Cassidy informed the Council that his plan was designed for the future guidance of the School and that it also could be used as a supportive document in approaching foundations for funds. S.D. Clark raised several concerns. He "questioned departmentally organized research and had reservations about the language used [in the memorandum] which he felt implied too much direction"; further, he felt that the decision to undertake any research "should rest wholly on whether or not it would be a scholarly piece of work." 64 On the other hand, Bernhardt and Tatham argued that "there might be some difference in research done in Departments of Sociology, Economics, Geography, etc. and in a School of Social Work." It was their contention that, while "pure research" could be done in a School of Social Work, it was also "important to undertake research where the findings. . [could] be applied towards the solution of human and community problems." ${ }^{65}$ Bernhardt spoke favourably about the significant departures suggested in the memorandum from the way in which university research was usually organized: "first, the establishment of funds for research within a Department and controlled by that Department; and secondly, overall planning rather than individuals following "hunches'." ${ }^{66}$ Dean MacFarlane was in favour of having the memorandum implemented so that the School could receive the funds needed to expand its research endeavours.

By the end of the meeting, the Council had passed a motion which supported in substance the Cassidy research plan. Subsequently, in May of 1951, the Board of Governors of the University approved a recommendation of President Smith that Cassidy "be permitted to appeal to the Atkinson Foundation for a grant or grants in support of Research in the School of Social Work." ${ }^{67}$ However, with Cassidy's death in November of 1951, action on the plans for research that he had promoted for more than a decade came to an end. ${ }^{68}$ Only recently has something of Cassidy's spirit been recaptured: in September of 1977, the Faculty of Social Work received a substantial development grant from the Connaught Fund at the University of Toronto to establish a major cooperative research program.

Many of the concerns that Cassidy and Innis raised during the 1940's about university social science research are still concerns today. For example, in his various proposals for a research institute, Cassidy stressed the importance of schools of social work undertaking historical studies of the development of Canadian social welfare. Yet in 1974, Canadian political scientist Alan Cairns, in an examination of various styles in the study of Canadian politics, concluded that "faculties of social welfare in Canada seem to have made almost no academic contribution to our understanding of the evolution of the welfare state." 69 Innis constantly emphasized the need for long-range interdisciplinary historical research that would explore the unique patterns of a society's evolution. However, social science research in Canada during the past thirty years, often influenced by developments in the United States, has become much more quantitative, specialized, and present-oriented, and has increasingly avoided the historical and theoretical approach that inspired Innis. ${ }^{70}$ These tendencies are likely to continue. One American academic sociologist envisions 
graduate students in the social sciences spending more and more time learning such things as computer skills and spending less and less time reading in the library. The trend is "toward technique and craft, and away from thought and theory." 71

Of all the questions raised by Cassidy and Innis, probably the most important for university social science research today relates to the degree of freedom from outside control or influence maintained by the researcher. Innis, especially, thought that university social science research should be undertaken in such a way that it was independent of and free from governmental control. Cassidy, too, although he promoted the involvement of academics in government research work, acknowledged the need to keep a great deal of university research free from political considerations. He, like Innis, recognized that only impartial research could be fundamental and critical.

During the 1970's, views similar to those of Innis and Cassidy increasingly have been expressed about the role and place of governments in university social science research: "The social sciences. . have been the victims of government funding and all the insidious bureaucratic and political controls that entails." 72 Donald Rowat entitled his 1976 presidential address to the annual meeting of the Canadian Political Science Association, "The Decline of Free Research in the Social Sciences", in which he focused on "the relative decline of independent research initiated by scholars themselves, as opposed to research commissioned and controlled by government." 73

Rowat estimated that the actual amount of funds devoted to scholar-initiated research (i.e., research funded through the Canada Council - now the Social Sciences and Humanities Research Council of Canada - and therefore subject to peer assessment unlike most contract research) is only about 7 per cent of total government expenditures for research and development in the social sciences. This is a reasonably accurate measure of how much federally financed social science research is free and independent; the remaining 93 per cent is conducted by government researchers themselves or is under government contract, often to academics. In short, it is either controlled or directed by governments. ${ }^{74}$

Government contract research has come more and more to have an insidious appeal for academic social scientists; an appeal that often ignores the question of whether the research to be undertaken is for the independent pursuit of truth. Governments usually want quick answers from researchers to some question of pressing public policy; this means that the more fundamental and reflective kind of research so favoured by Innis is neglected.

In his 1976 presidential address, Rowat condemned the contract research system in words that Innis himself might have chosen: "It shifts the interests of academics into narrow problems of immediate concern to the government and away from broad ones of long-term concern to society as a whole." 75 Rowat went on to propose that, in order to preserve free and independent research and ultimately the integrity of the university, universities and academics should refuse to participate in all forms of government contract research. Although this is perhaps a somewhat extreme position, it is one that Innis would undoubtedly have supported.

When Innis undertook his massive investigations into Canadian economic history, he did so supported entirely by his university salary which was then meagre enough. To suggest, however, that all social science research today should be supported entirely by 
108 Allan Irving

scholars themselves would be to become preoccupied quixotically with the past; in any case, the kind of social science research now undertaken relies heavily on the extensive use of the computer and does require large infusions of funds.

Innis, undoubtedly, would have been dismayed by the direction taken by Canadian academic social science in the 1960's and 1970's; Cassidy would have been disturbed less, although he too would have been concerned about the drift towards government control. Both would have fully agreed with Karl Jaspers's statement that "it is a human right that man must be allowed somewhere to pursue truth unconditionally and for its own sake" and would have seen the university as the ideal place for such activity. ${ }^{76}$ The 1980 's may be an appropriate time for the social sciences to return to the balance and perspective that are essential for the integrity of the university, and that Innis feared had been lost forever.

\section{FOOTNOTES}

1. Cassidy to H.J. Cody, June 22, 1934, H.M. Cassidy Papers, University of Toronto Archives (B72-022, Box 61).

2. For accounts of the League, see Michiel Horn, "The League for Social Reconstruction: Socialism and Nationalism in Canada 1931-1945" (Unpublished Ph.D. thesis, University of Toronto, 1969), and "The League for Social Reconstruction and the Development of a Canadian Socialism, 1932-1936," Journal of Canadian Studies VII, no. 4 (November 1972), 3-17.

3. Quoted in Carl Berger, The Writing of Canadian History: Aspects of English-Canadian Historical Writing, 1900-1970 (Toronto: Oxford University Press, 1976), 110.

4. Ibid.

5. For a brief but excellent account of Innis's life and work, see Donald Creighton, Harold Adams Innis: Portrait of a Scholar (Toronto: University of Toronto Press, 1957, 19.78).

6. J.B. Brebner, "Harold Adams Innis as Historian," Canadian Historical Association Report (1953), 17.

7. Harold A. Innis, The Fur Trade in Canada (New Haven: Yale University Press, 1930), 397.

8. Berger, Writing of Canadian History, 85.

9. Brebner, "Innis as Historian," 22.

10. Ralph Heintzman, "Quebec and the Empire of the St. Lawrence," Journal of Canadian Studies XII, no. 5 (Winter 1977), 2 .

11. For an account of the government under which Cassidy worked, see Margaret A. Ormsby, "T. Dufferin Pattullo and the Little New Deal," Canadian Historical Review XLIII, no. 4 (December 1962), 277-297.

12. Allon Peebles, "Harry Morris Cassidy, 1900-1951," Canadian Welfare XXVII, no. 6 (December 1951), 5 .

13. Two articles which also have been helpful in the preparation of this section are William Christian, "Harold Innis as Political Theorist," Canadian Journal of Political Science X, no. 1 (March 1977), 21.42; and Leslie A. Pal, "Scholarship and the Later Innis," Journal of Canadian Studies XII, no. 5 (Winter 1977), 32-44.

14. Marshall McLuhan, "The Later Innis," Queen's Quarterly LX, no. 3 (Autumn 1953), 392.

15. Marshall McLuhan, Introduction to The Bias of Communication by Harold A. Innis (Toronto: University of Toronto Press, 1951), xii.

16. Berger, Writing of Canadian History, 189.

17. Innis, Bias of Communication, 64 .

18. Ibid., 141. 
109 Social Science Research in the University: An Examination of the Views

19. Ibid., 30.

20. Harold A. Innis, Political Economy in the Modern State (Toronto: The Ryerson Press, 1946), x.

21. Ibid., 71.

22. See Harold Innis, "This Has Killed That," Journal of Canadian Studies XII, no. 5 (Winter 1977). The editor of the Journal of Canadian Studies has stated that this article is "a slightly edited version of an unpublished, undated address delivered by Harold Innis sometime during the Second World War."

23. Innis, Political Economy, 65.

24. Innis, Bias of Communication, 84-85.

25. Innis, Political Economy, $75,76$.

26. Ibid., 69.

27. H.A. Innis, "For the People," University of Toronto Quarterly V, no. 2 (January 1936), 285.

28. Innis, Bias of Communication, 86.

29. H.A. Innis, "The Role of Intelligence: Some Further Notes," Canadian Journal of Economics and Political Science I, no. 2 (May 1935), 283.

30. Innis, Bias of Communication, 190.

31. Innis, Political Economy, 125.

32. H.A. Innis, "The Social Sciences in the Post-War World," Canadian Historical Review XXII, no. 2 (June 1941), 119.

33. Innis, Bias of Communication, 203.

34. Ibid., 191.

35. Ibid., 90.

36. McLuhan, Introduction to The Bias of Communication, xi.

37. Cassidy to H.J. Cody, August 7, 1939, Presidents' Papers, University of Toronto Archives (A68006, Box 31). Unless otherwise indicated, all subsequent references are drawn from the Presidents' Papers.

38. Cassidy to Cody, April 10, 1943 (Box 44).

39. H.M. Cassidy, "Research in Social Security - A Plan for an Institute at the University of Toronto" (Spring 1943), 1 (Box 49).

40. Ibid.

41. Ibid., 3 .

42. Ibid., 7 .

43. Ibid., 7-8.

44. Ibid., 8.

45. Ibid., 12-19.

46. Ibid., 13.

47. Ibid., 8.

48. Ibid., 32

49. Cody to Cassidy, May 8, 1944 (Box 49).

50. Cassidy to Cody, June 26, 1944 (Box 49).

51. H.M. Cassidy, "A Programme for the School of Social Work" (April 1945), 4, 12 (Box 54).

52. Ibid., 12.

53. H.M. Cassidy, "Research in the School of Social Work" (March 1946), 9 (Box 69).

54. H.M. Cassidy, "Some Principles of School Policy" (September 1949), 7, H.M. Cassidy Papers, University of Toronto Archives (Box 53).

55. Ibid., 8.

56. Ibid., 7-8. 
110 Allan Irving

57. H.M. Cassidy, "Research in Social Welfare" (April 1951), 14 (Box 170).

58. Ibid., 15.

59. Ibid, 38.

60. Ibid., 63,65 .

61. Ihid., 5 .

62. There were several versions of this memorandum. While the final one (the one referred to in this article) was dated April 1951, earlier drafts had been available and discussed since the previous autumn.

63. Berger, Writing of Canadian History, 168.

64. Minutes of the Meeting of the Council of the School of Social Work, February 22, 1951, School of Social Work Papers, University of Toronto Archives (A70-004, Box 9).

65. Ibid.

66. Ibid.

67. Minutes of the Meeting of the Board of Governors of the University of Toronto, May 17, 1951, Board of Governors Papers, University of Toronto Archives (A7-0024, vol. 38).

68. Several reasons may be advanced to explain why Cassidy's earlier appeals for the establishment of a separate research institute within the School of Social Work were disregarded. Lack of funds undoubtedly was one reason; more important, perhaps, was the general lack of enthusiasm in the University community, particularly on the part of members of the Department of Political Economy such as Innis and Clark, for Cassidy's conception of social welfare research. As well, Innis's increasing influence as Dean of the Graduate School after 1947 was probably a factor in delaying the Cassidy proposals.

69. Alan C. Cairns, "Alternative Styles in the Study of Canadian Politics," Canadian Journal of Political Science VII, no. 1 (March 1974), 109.

70. For a discussion of this drift towards a quantitative approach in political science and economic history, see Reginald Whitaker, "'Confused Alarms of Struggle and Flight': English-Canadian Political Science in the 1970's," Canadian Historical Review LX, no. 1 (March 1979), 1-18; and Hugh G.J. Aitken, "Myth and Measurement: The Innis Tradition in Economic History," Journal of Canadian Studies XII, no. 5 (Winter 1977), 96-105.

71. Karl Schuessler, "Sociology Toward the Year 2000," Society XVI, no. 5 (July/August 1979), 32. This issue of Society contains a number of articles on the general topic, "Crisis in Social Science?"

72. Jack D. Douglas, "Future Perils," Society XVI, no. 5 (July/August 1979), 61.

73. Donald C. Rowat, "The Decline of Free Research in the Social Sciences," Canadian Journal of Political Science IX, no. 4 (December 1976), 537.

74. Ibid., 538, 539 .

75. Ibid., 543 .

76. Karl Jaspers, The Idea of the University (Boston: Beacon Press, 1959), 1. 